\author{
IN THIS ISSUE \\ DUNCAN HILCHEY
}

\section{Food systems research priorities: Blueprints for the next 5 years}

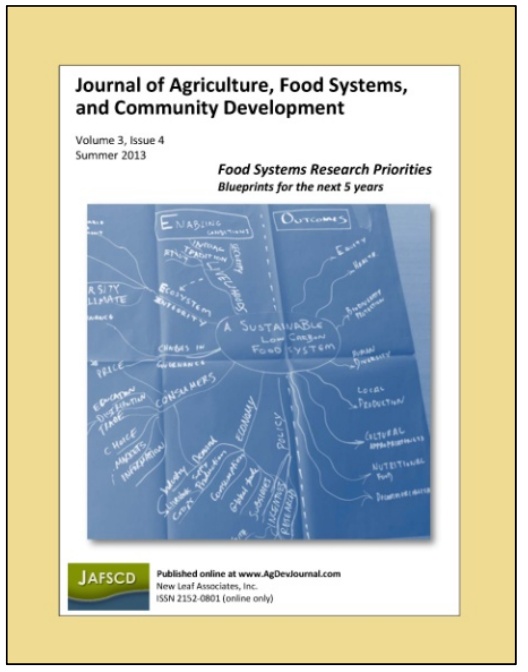

Published online September 30, 2013

Citation: Hilchey, D. L. (2013). Food systems research priorities: Blueprints for the next 5 years [Editorial]. Journal of Agriculture, Food Systems, and Community Development, 3(4), 1-3. http://dx.doi.org/10.5304/jafscd.2013.034.028

Copyright (C) 2013 by New Leaf Associates, Inc.

$\mathrm{I}^{\mathrm{n}}$ $\mathrm{n}$ this issue we offer 26 commentaries from around the world on food systems research priorities. The cover of this issue was created from one of the group outputs of a team of 28 young scholars who convened from five continents to take a transdisciplinary look at future food systems research (see RiveraFerre et al.).

In our call for papers, we encouraged commentaries from farm and consumer organizations, research groups, agencies, and any other stakeholders on what they felt are the key applied research priorities for the community development aspects of food systems. We framed the call in terms of filling the gaps in research and the literature with the hope that this collection of commentaries will encourage new thinking and approaches to food systems over the next few years.

Indeed, the commentaries that arrived reflected the views of researchers and practitioners from dozens of countries and covered a remarkable range of topics. Some are written by individuals while a good number are written by both formal and ad hoc research groups. We were especially pleased to see several commentaries that came out of collaborative discussions of researchers and practitioners.

The commentaries themselves cover a very broad swath of food systems subjects with local, regional, national, and global scopes. Most reflect on the existing literature and propose key questions that they hope to work on or encourage others to work on. In an attempt to organize the commentaries thematically, I created a very simple typology (see below) using three broad food systems domains for the rows (Production, Distribution, Consumption, plus a fourth trans-system category I simply call "Systems Perspective"), and three general sustainability domains for the columns (Social, Economic, and Environmental, plus a fourth trans-sustainability category called "Holistic Perspective"). The resulting typology consists of 16 cells into which the papers loosely fit. Of course a number of papers could have fallen into several cells; I've categorized them by the predominance of their topical narrative.

A cursory review of this typology suggest that we've aggregated a pretty encompassing collection of commentaries on future food systems research priorities. The largest number of commentaries fit into what might be called the "sustainable systems perspective" domain (cell 4/D), while most of the other cells 
had one or two commentaries. A few possible holes (cells labeled "None") relate to the economics of production (cell 1/B), which is not a focal area of JAFSCD, and environmental aspects of distribution (cell $2 / \mathrm{C}$ ). The lack of commentaries in $2 / \mathrm{C}$ is surprising since, for example, life-cycle analysis or carbon footprinting are critical topics in understating the sustainability of regional food distribution systems. Dare I provocatively suggest it is not a priority because we are not likely to find a flattering result? Chances are it is simply the luck of the draw, but feel free to comment constructively on this issue using the comment feature.

In any case, this was my crack at categorizing the commentaries; I welcome thoughtful, constructive feedback on my approach and my interpretation of the results.

Please note that all the commentaries in this issue are open access - you do not need to be a subscriber to download the full-content PDFs, and we encourage discourse about the commentaries through the commenting feature on the website. (This can be found just below the PDF on each commentary's page.) Consider not only commenting but also downloading these commentaries and sharing them with your colleagues, your organization's or agency's partners, as well as in the classroom. They would be especially valuable in graduate seminars to stimulate creative thinking about the food systems issues we face and the research that is needed to help crack these challenges and opportunities.

Complementing these 26 commentaries, JAFSCD columnists Kate Clancy and John Ikerd offer their own takes on food systems research priorities. Kate explores and expands on four recommendations contained in the National Research Council (NRC) publication, Toward Sustainable Agricultural Systems in the 21 st Century, and John challenges us to rethink and redesign our basic approach to research altogether!

In addition to our commentaries and columns, we also offer one open-call paper, Commercial Bakers' View on the Meaning of "Local" Wheat and Flour in Western Washington State. Authors Karen M. Hills, Jessica R. Goldberger, and Stephen S. Jones surveyed bakers to identify opportunities and challenges in creating new regional value chains.

Finishing off this colossal issue is Christian Man's review of Farming the City: Food as a Tool for Today's Urbanisation, edited by Francesca Miazzo and Mark Minkjan of CITIES.

Finally, I want to express my deepest appreciation to managing editor Amy Christian for her extra effort in preparing this issue, which includes twice the normal number of manuscripts. While the commentaries were not peer-reviewed, they did require considerable time to proof-read and format (including many evening hours). The JAFSCD community is lucky indeed to have such a talented and dedicated editor at the core of this publication.

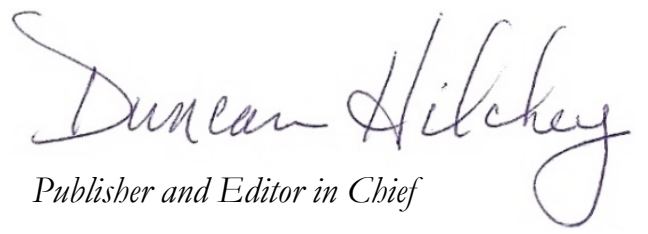


Typology of the Food Systems Research Commentaries in This Issue (Each title is hyperlinked to the online version)

\begin{tabular}{|c|c|c|c|c|c|}
\hline & & \multicolumn{4}{|c|}{ Sustainability Domains } \\
\hline & & A. Social & B. Economic & C. Environmental & D. Holistic Perspective \\
\hline & $\begin{array}{c}1 . \\
\text { Production }\end{array}$ & $\begin{array}{l}\text { - White Spaces in Black } \\
\text { and Latino Places: Urban } \\
\text { Agriculture and Food } \\
\text { Sovereignty (Hoover) }\end{array}$ & None & $\begin{array}{l}\text { - Critical Research Needs } \\
\text { for Successful Food Sys- } \\
\text { tems Adaptation to Cli- } \\
\text { mate Change (Miller et al.) } \\
\text { - Research Priorities for } \\
\text { Advancing Adoption of } \\
\text { Cover Crops in Agriculture- } \\
\text { intensive Regions (Carlson } \\
\text { \& Stockwell) } \\
\text { - Closing the Knowledge } \\
\text { Gap: How the USDA Could } \\
\text { Tap the Potential of } \\
\text { Biologically Diversified } \\
\text { Farming Systems (Carlisle } \\
\text { \& Miles) } \\
\end{array}$ & $\begin{array}{l}\text { - Crop Diversification: A } \\
\text { Potential Strategy To } \\
\text { Mitigate Food Insecurity } \\
\text { by Smallholders in Sub- } \\
\text { Saharan Africa (Njeru) } \\
\text { - Future Research } \\
\text { Approaches To } \\
\text { Encourage Small-scale } \\
\text { Fisheries in the Local } \\
\text { Food Movement (Nelson } \\
\text { et al.) }\end{array}$ \\
\hline & $\begin{array}{l}2 . \\
\text { Distribution }\end{array}$ & $\begin{array}{l}\text { - Advancing Rural Food } \\
\text { Access Policy Research } \\
\text { Priorities: Process and } \\
\text { Potential of a Transdis- } \\
\text { ciplinary Working Group } \\
\text { (Fleischhacker et al.) }\end{array}$ & $\begin{array}{l}\text { - The Role of Food Hubs in } \\
\text { Food Supply Chains } \\
\text { (Matson \& Thayer) }\end{array}$ & None & $\begin{array}{l}\text { - Researching Market and } \\
\text { Supply-Chain Opportuni- } \\
\text { ties for Local Foods } \\
\text { Systems: Setting Priorities } \\
\text { and Identifying Linkages } \\
\text { (Thilmany et al.) }\end{array}$ \\
\hline & $\begin{array}{c}3 . \\
\text { Consumption }\end{array}$ & $\begin{array}{l}\text { - Including the Voices of } \\
\text { Communities in Food } \\
\text { Insecurity Research: An } \\
\text { Empowerment-based } \\
\text { Agenda for Food Schol- } \\
\text { arship (Pine \& de Souza) }\end{array}$ & $\begin{array}{l}\text { - Rethinking Research: } \\
\text { Creating a Practice-Based } \\
\text { Agenda for Sustainable } \\
\text { Small-Scale Healthy Food } \\
\text { Retail (Karpyn \& Burton- } \\
\text { Laurison) }\end{array}$ & $\begin{array}{l}\text { - Food Sovereignty and } \\
\text { Agricultural Land Use } \\
\text { Planning: The Need To } \\
\text { Integrate Public Priorities } \\
\text { Across Jurisdictions } \\
\text { (Connell et al.) }\end{array}$ & $\begin{array}{l}\text { - Alternative Food Systems } \\
\text { and the Citizen-consumer } \\
\text { (Lehner) }\end{array}$ \\
\hline 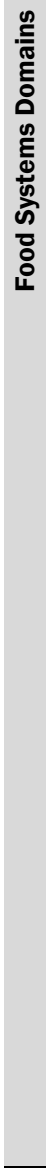 & $\begin{array}{c}4 . \\
\text { Systems } \\
\text { Perspective }\end{array}$ & $\begin{array}{l}\text { - Participation and Invest- } \\
\text { ment in Local Agriculture: } \\
\text { What's in a Community? } \\
\text { (Fazzino et al.) } \\
\text { - Going "Beyond Food": } \\
\text { Confronting Structures of } \\
\text { Injustice in Food Systems } \\
\text { Research and Praxis } \\
\text { (Passidomo) }\end{array}$ & $\begin{array}{l}\text { - A Regional Economics- } \\
\text { Based Research Agenda } \\
\text { for Local Food Systems } \\
\text { (Boys \& Hughes) } \\
\text { - Economic Impacts of Local } \\
\text { Food Systems: Future } \\
\text { Research Priorities } \\
\text { (O'Hara \& Pirog) }\end{array}$ & $\begin{array}{l}\text { - The New Environmental } \\
\text { Security: Linking Food, } \\
\text { Water, and Energy for } \\
\text { Integrative and Diagnostic } \\
\text { Social-ecological } \\
\text { Research (Loring et al.) }\end{array}$ & $\begin{array}{l}\text { - A Research Agenda for } \\
\text { Food System Transfor- } \\
\text { mation Through Autono- } \\
\text { mous Community-based } \\
\text { Food Projects (Born) } \\
\text { - Toward Alternative Food } \\
\text { Systems Development: } \\
\text { Exploring Limitations and } \\
\text { Research Opportunities } \\
\text { (Albrecht et al.) } \\
\text { - Food Webs and Food } \\
\text { Sovereignty: Research } \\
\text { Agenda for Sustainability } \\
\text { (Francis et al.) } \\
\text { - Feeding Cities: Charting a } \\
\text { Research and Practice } \\
\text { Agenda Toward Food } \\
\text { Security (Brinkley et al.) } \\
\text { - Methodologies for Iden- } \\
\text { tifying Food System } \\
\text { Research Priorities: } \\
\text { Dispatch from Alaska } \\
\text { (Snyder \& Donovan) } \\
\text { - Future Food System Re- } \\
\text { search Priorities: A Sus- } \\
\text { tainable Food Systems } \\
\text { Perspective from Ontario, } \\
\text { Canada (Blay-Palmer et al.) } \\
\text { - The Next Food Systems } \\
\text { Agenda: A Western } \\
\text { Grassroots Perspective } \\
\text { (Rasmussen et al.) } \\
\text { - A Vision for Transdisci- } \\
\text { plinarity in Future Earth: } \\
\text { Perspectives from Young } \\
\text { Researchers (Rivera-Ferre } \\
\text { et al.) } \\
\end{array}$ \\
\hline
\end{tabular}

